\title{
ANALISA USAHATANI KEDELAI VARIETAS WILIS PADA LAHAN SAWAH TADAH HUJAN DI DESA KLOMPANG BARAT KECAMATAN PAKONG KABUPATEN PAMEKASAN
}

\author{
Zainol Arifin *, Sahrawi * \\ *Dosen Fakultas Pertanian Universitas Islam Madura \\ Imail: zainol_arifin99@yahoo.co.id
}

\begin{abstract}
ABSTRAK
Kedelai merupakan tanaman pangan yang penting sebagai sumber protein nabati. Permintaan dan kebutuhan masyarakat semakin meningkat, sedangkan produksi dalam negeri belum mencukupi, untuk mengatasinya pemerintah masih mengimpor. Hal ini disebabkan karena produksi yang masih rendah untuk itu diupayakan penelitian terus menerus untuk meningkatkan produktivitas. Penelitian ini bertujuan untuk mengetahui : Biaya produksi dan pendapatan petani, serta mengetahui faktor-fakor yang mempengaruhi usahatani kedelai. Penelitian ini dilaksanakan di Desa Klompang Barat Kecamatan Pakong Kabupaten Pamekasan. Pada Bulan Juni sampai Agustus 2012, metode penggunaan sampel penelitian dengan cara Simple Random Sampling artinya penggunaan sampel dilakukan secara acak sederhana. Jumlah populasi sebanyak 20 orang, terdiri dari : 10 orang responden/petani dari kelompok tani " Margo Rukun " dan 10 orang responden/petani dari kelompok tani " Taman Sari ". pengumpulan data dilakukan dengan 2 ( Dua ) cara yaitu data primer dan data sekunder. Hasil analisa usahatani kedelai menunjukkan bahwa Biaya produksi usahatani Kedelai secara ekonomis menguntungkan Dan Pendapatan bersih usahatani kedelai sudah mencukupi yaitu rata rata R/C Ratio Per Ha Per Musim Tanam adalah 1,56. Dari hasil Penerimaan ( TR ) yaitu sebesar Rp 5,108,642,- dibagi Total Produksi ( TC ) yaitu sebesar Rp 3,265,452. Dan Pendapatan bersih usahatani kedelai sudah mencukupi yaitu sebesar Rp 1,843,191,-- Dari hasil Penerimaan ( TR ) yaitu sebesar Rp 5,108,642,- dikurangi Total Produksi ( TC ) sebesar Rp 3,265,452,- .Produksi, Luas lahan, Pupuk, Tenaga kerja, Pendidikan dan Pengalaman bertani sangat berpengaruh terhadap usahatani kedelai di daerah penelitian.
\end{abstract}

Kata Kunci : Usahatani, Kedelai. Varietas Willis.

PENDAHULUAN

\section{Latar Belakang}

Kedelai (Glycine max (L.) Merrill) merupakan tanaman pangan yang penting sebagai sumber protein nabati. Permintaan dan kebutuhan masyarakat semakin meningkat, sedangkan produksi dalam negeri belum mencukupi, untuk mengatasinya pemerintah masih mengimpor. Impor ini pun dari tahun ke tahun terus meningkat (Manwan dan Sumarno, 1991). Hal ini disebabkan karena produksi yang masih rendah untuk itu diupayakan penelitian terusmenerus untuk meningkatkan produktivitas. Kedelai dibutuhkan untuk memenuhi kebutuhan protein 
murah bagi masyarakat dalam upaya meningkatkan kualitas sumberdaya manusia Indonesia. Sejalan dengan pertambahan jumlah penduduk maka permintaan akan kedelai semakin meningkat. Untuk itu diperlukan program khusus peningkatan produksi kedelai dalam negeri. (Deptan, 2008).

Produksi kedelai nasional secara nasional tahun 2009 diperkirakan sebesar 966.469 ton naik 190.759 ton (24,59 persen) dibanding tahun 2008 yang sebesar 775.710 ton. Kenaikan ini diperkirakan terjadi karena kenaikan luas panen sebesar 137.244 hektar (23,22 persen) dari 590.956 hektar pada tahun 2008 menjadi 728.200 hektar pada tahun 2009 dan kenaikan produktivitas sebesar 0,14 $\mathrm{Kw} / \mathrm{Ha}(1,07$ persen) dari 13,13 Kw/Ha pada tahun 2008 menjadi 13,27Kw/Ha pada tahun 2009 (Badan Pusat Statistik). Kebutuhan nasional untuk kedelai mencapai 2,2 juta ton per tahun. Namun demikian, baru 20 sampai $30 \%$ saja dari kebutuhan tersebut yang dapat dipenuhi oleh produksi dalam negeri. Sementara 70 sampai $80 \%$ kekurangannya bergantung pada impor. Ketergantungan terhadap impor ini membuat instansi terkait sulit untuk mengontrol harga kedelai. (setneg. 2009).

Dengan memahami betapa
besarnya kebutuhan kedelai untuk
pasokan industri yang menghasilkan

bahan pangan bagi sebagian besar penduduk Indonesia tersebut di satu sisi, sedangkan disisi lain impor cenderung meningkat, maka dalam kondisi perekonomian seperti saat-saat ini, berbagai upaya yang dapat mengarah kepada memproduksikan kedelai dalam negeri secara optimal agar negara dapat memperkecil kedelai impor, merupakan momentum yang tepat untuk menggerakan masyarakat apakah dari kalangan perbankan, perusahaan besar selaku mitra, kalangan petani, instansi terkait, dan instansi lainnya, untuk menyatu dalam suatu pelaksanaan proyek dalam rangka meningkatkan produksi kedelai dalam negeri.

Provinsi Jawa Timur sebagai sentra kedelai Indonesia, produksinya mencapai $33 \%$ total produksi nasional, menjadi andalan utama dalam upaya pencapaian swasembada kedelai. Produktifitas kedelai di Jawa Timur rata-rata baru mencapai 1,243 ton/ha. Meskipun angka produktifitas tersebut sudah lebih tinggi dari rata-rata produksi nasional yaitu 1,1 ton/ha tetapi sasaran produktifitas nasional adalah 1,372 ton/ha dan harus ditingkatkan sampai 1,8 ton/ha untuk dapat mencapai swasembada kedelai.oleh karena itu Jawa Timur masih perlu meningkatkan produktivitas kedelainya sebesar 557 $\mathrm{kg} / \mathrm{ha}$, guna memenuhi target swasembada kedelai. ( BPTP, 1999) 
Untuk meningkatkan laju produksi kedelai beberapa aspek perlu mendapatkan perhatian, misalnya luas tanam dan panen, kualitas sumber daya lahan, mutu benih dan varietas, tingkat pengelolaan lahan pertanaman, panen dan pasca panen serta rekayasa teknologi budidaya kedelai baik teknis, ekonomis dan sosial kelembagaan. Aspek-aspek tersebut harus dikemas dalam bentuk program yang terpadu dan berkesinambungan serta didukung oleh kebijakan pemerintah yang kondusif agar tercapai hasil yang optimal. (BPTP, 1999). Berdasarkan uraian di atas maka penulis tertarik untuk melakukan penelitian guna mengetahui analisa usahatani kedelai varietas willis pada petani Desa Klompang Barat Kecamatan Pakong Kabupaten Pamekasan.

\section{METODE PENELITIAN}

\section{Waktu dan Lokasi Penelitian}

Penelitian ini dilakukan di Desa Klompang Barat Kecamatan Pakong Kabupaten Pamekasan. Penentuan lokasi penelitian dilakukan secara Purposive dengan pertimbangan bahwa sebagian besar petani di desa Klompang Barat tergabung dalam Kelompok Tani.Waktu pelaksanaan penelitian ini akan dilaksanakan pada 3 bulan, dari bulan Juni sampai Agustus 2012.

\section{Teknik dan Analisa Data}

Komoditi kedelai merupakan komoditi yang diambil dari penelitian ini sehingga contoh / responden yang diambil dari penelitian ini adalah petani. Metode ini menggunakan metode simple random sampling. Dengan menggunakan metode pengambilan contoh diatas maka sampel penelitian adalah kelompok tani “ Taman Sari “ dengan jumlah anggota 161 orang dan “ Margo Rukun “ dengan jumlah anggota 113 orang di desa Klompang Barat. Adapun responden yang dijadikan sasaran penelitian adalah anggota kelompok tani “ Taman Sari " dan “ Madu Sari “ dengan jumlah 20 orang responden/petani sebagai sampel.

\section{Analisa R/C Rasio}

Penelitian ini menggunakan Analisa Revenue Cost Ratio ( Rasio R/C) adalah perbandingan antara penerimaan dengan total biaya produksi. Analisis R/C Rasio dapat di hitung dengan rumus sebagai berikut :

$\mathrm{a}=\mathrm{R} / \mathrm{C}$

$\mathrm{R}=\mathrm{Py} \cdot \mathrm{Y}$

$\mathrm{C}=\mathrm{FC}+\mathrm{VC}$

$\mathrm{A}=\{(\mathrm{Py} \cdot \mathrm{Y}) /(\mathrm{FC}+\mathrm{VC})\}$

Dimana :

$\mathrm{R}=$ Penerimaan (Revenue)

$\mathrm{C}=$ Biaya $($ Cost $)$

Py = Harga Output

$\mathrm{Y}=$ Output

FC = Biaya Tetap ( Fixed cost $)$

$\mathrm{VC}=$ Biaya V ariabel ( Variabel cost)

Indikatornya adalah sebagai berikut : 
- $\quad$ Bila $\mathrm{R} / \mathrm{C}=1$ maka petani kedelai tersebut tidak untung dan tidak rugi.

- $\quad$ Bila $\mathrm{R} / \mathrm{C}<1$ maka petani kedelai tersebut rugi.

- Bila $\mathrm{R} / \mathrm{C}>1$ maka petani kedelai tersebut untung.

( Soekartawi, 1995)

\section{Analisa Pendapatan ( $\pi$ )}

Penelitian ini menggunakan

Analisa Pendapatan agar mengetahui selisih antara penghasilan total (TR) dengan pembiayaan total (TC). Dan supaya mendapatkan pendapatan yang maksimum. Analisa pendapatan dapat dihitung dengan rumus sebagai berikut:

$(\pi)=\mathrm{TR}-\mathrm{TC}$

Dimana :

$(\pi)=$ Pendapatan

$\mathrm{TR}=$ Total Revenue (Total penerimaan)

( $\mathrm{Rp}$ )

$\mathrm{TC}=$ Total Cost $($ Total Biaya $)(\mathrm{Rp})$

( Soekartawi, 1995)

\section{HASIL DAN PEMBAHASAN}

Kegiatan Usahatani Kedelai di Desa Klompang Barat

Kegiatan usahatani di Desa Klompang Barat terdiri dari pengolahan lahan, pemberian pupuk, penanaman, pemeliharaan, pemberantasan hama dan penyakit, serta panen.

\section{Pengolahan lahan}

Lahan harus diolah dahulu sebelum ditanami. Pengolahan lahan bertujuan untuk memperbaiki kondisi tanah agar sesuai dengan yang diinginkan oleh tanaman kedelai, yaitu tanah yang gembur dan subur. Terdapat 2 cara mempersiapkan penanaman kedelai, yakni: persiapan tanpa pengolahan tanah (ekstensif) di sawah bekas ditanami padi rendheng dan persiapan dengan pengolahan tanah (intensif). Persiapan tanam pada tanah tegalan atau sawah tadah hujan sebaiknya dilakukan 2 kali pencangkulan.

\section{Pemberian pupuk}

Dosis pupuk yang digunakan sangat tergantung pada jenis lahan dan kondisi tanah. Pada tanah subur atau tanah bekas ditanami padi dengan dosis pupuk tinggi, pemupukan tidak diperlukan. Pada tanah yang kurang subur, pemupukan dapat menaikkan hasil.

\section{Penanaman}

Tanah yang telah diolah sudah siap untuk ditanami, jika areal luas dan pengolahan tanah dilakukan dengan pembajakan, penanaman benih dilakukan menurut alur bajak sedalam kira-kira $5 \mathrm{~cm}$. Sedangkan jarak jarak antara alur yang satu dengan yang lain dapat dibuat 50-60 cm, dan anda jarak tanam dibuat $20 \mathrm{~cm}$. Karena umur kedelai menurut varietas yang dianjurkan berkisar antara 75-120 hari, maka sebaiknya kedelai ditanam menjelang akhir musim penghujan, 
yakni saat tanah agak kering tetapi masih mengandung cukup air. Waktu tanam yang tepat pada masing-masing daerah sangat berbeda.

\section{Pemeliharaan Tanaman}

Pemeliharaan tanaman yang dilakukan secara baik dan benar akan menghasilkan produktivitas tanaman yang tinggi. Kegiatan pemeliharaan tanaman kedelai di daerah penelitian meliputi : penyiraman dan penyiangan.

\section{a. Penyiraman}

Kedelai menghendaki kondisi tanah yang lembab tetapi tidak becek. Kondisi seperti ini dibutuhkan sejak benih ditanam hingga pengisian polong. Saat menjelang panen, tanah sebaiknya dalam keadaan kering. Kekurangan air pada masa pertumbuhan akan menyebabkan tanaman kerdil, bahkan dapat menyebabkan kematian apabila kekeringan telah melalui batas toleransinya. Kekeringan pada masa pembungaan dan pengisian polong dapat menyebabkan kegagalan panen.

\section{b. Penyiangan}

tanaman kedelai dilakukan pada umur 2-3 minggu. Penyiangan ke-2 dilakukan pada saat tanaman selesai berbunga, sekitar 6 minggu setelah tanam. Penyiangan ke-2 ini dilakukan bersamaan dengan pemupukan ke-2 (pemupukan lanjutan). Penyiangan dapat dilakukan dengan cara mengikis gulma yang tumbuh dengan tangan atau kuret.

\section{Penyemprotan Pestisida}

Penyemprotan pestisida dilakukan pada waktu yang berbedabeda tergantung jenis hama dan pola penyerangannya

\section{Panen}

Kegiatan pemanenan tanaman kedelai di daerah penelitian meliputi : Pengumpulan dan Pengeringan, Penyortiran dan Penggolong, serta Penyimpanan dan pengemasan.

\section{a. Pengumpulan dan Pengeringan}

Tanaman kedelai yang telah berumur 3 bulan sejak sebar benih sudah dapat dipanen. Setelah pemungutan selesai, seluruh hasil panen hendaknya segera dijemur. Kedelai dikumpulkan kemudian dijemur di atas tikar, anyaman bambu, atau di lantai semen selama 3 hari.

\section{b. Penyortiran dan Penggolong} Terdapat beberapa cara untuk memisahkan biji dari kulit polongan. Diantaranya dengan cara memukul-mukul tumpukan brangkasan kedelai secara langsung dengan kayu atau brangkasan kedelai sebelum dipukul - pukul 
dimasukkan ke dalam karung atau dirontokkan dengan alat pemotong

\section{c. Penyimpanan dan pengemasan}

Sebagai tanaman pangan, kedelai dapat disimpan dalam jangka waktu cukup lama. Caranya kedelai disimpan di tempat kering dalam karung. Karung-karung kedelai ini ditumpuk pada tempat yang diberi alas kayu agar tidak langsung menyentuh tanah atau lantai. Apabila kedelai disimpan dalam waktu lama, maka setiap 2-3 bulan sekali harus dijemur lagi sampai kadar airnya sekitar $9-11 \%$.

Analisa Usahatani Kedelai Varietas

\section{Willis}

\section{Analisa Biaya Produksi Usahatani}

\section{Kedelai}

Biaya usahatani kedelai adalah keseluruhan biaya yang dikeluarkan

Tabel 1. Analisa Produksi Usahatani Kedelai Varietas Willis Per Ha Musim Tanam di Desa Klompang Barat.

\begin{tabular}{|c|c|c|c|c|c|c|c|}
\hline No & Uraian & Satuan & Unit & $\begin{array}{c}\text { Harga } \\
(\mathrm{Rp})\end{array}$ & $\begin{array}{l}\text { Nilai } \\
\text { (Rp) }\end{array}$ & $\begin{array}{c}\text { Jumlah } \\
\text { (Rp) }\end{array}$ & $\begin{array}{c}\text { Persentase } \\
(\%)\end{array}$ \\
\hline & \multicolumn{7}{|l|}{ Biaya Tetap } \\
\hline \multirow[t]{3}{*}{1.} & Pajak Lahan & & & & 60,774 & & \\
\hline & \multicolumn{4}{|c|}{ TOTAL BIAY A TETAP } & & 60,774 & 100 \\
\hline & \multicolumn{7}{|l|}{ Biaya Variabel } \\
\hline 1. & Benih & $\mathrm{Kg}$ & 46 & 6,775 & 310,339 & & 8.65 \\
\hline \multirow[t]{3}{*}{2.} & Pupuk & & & & & & \\
\hline & Urea & $\mathrm{Kg}$ & 203 & 2,085 & 423,188 & 423,188 & 11.80 \\
\hline & TSP & $\mathrm{Kg}$ & 95 & 2,205 & 209,119 & 209,119 & 5.83 \\
\hline \multirow[t]{4}{*}{3.} & Pestisida & & & & & & \\
\hline & Buldog & Botol & 7 & 18,222 & 135,850 & 135,850 & 3.79 \\
\hline & Kanon & Botol & 7 & 11,125 & 75,363 & 75,363 & 2.10 \\
\hline & Drusban & Botol & 6 & 12,600 & 73,900 & 73,900 & 2.06 \\
\hline
\end{tabular}

kedqladi. Dalam penelitian ini biaya usahatani dibagi menjadi dua, yaitu biaya tetap dan biaya variabel. Biaya tetap dalam usahatani ini adalah biaya yang dikeluarkan petani dan tidak mempengaruhi output yang dihasilkan. Sedangkan biaya variabel adalah biaya yang dikeluarkan oleh petani yang dapat mempengaruhi besarnya output yang dihasilkan. 


\begin{tabular}{rcrrrrr} 
Pupuk Cair & Botol & 10 & 10,000 & 96,774 & 96,774 & 2.70 \\
4. Tenaga Kerja & & & & & & \\
Olah tanah & HKO & 10 & 47,000 & 448,774 & 448,774 & 12.51 \\
Penanaman & HKO & 9 & 14,375 & 135,403 & 135,403 & 3.77 \\
Penyiangan & HKO & 37 & 14,375 & 536,048 & 536,048 & 14.94 \\
Pemupukan I & HKO & 9 & 14,250 & 121,355 & 121,355 & 3.38 \\
Pemupukan II & HKO & 8 & 13,600 & 114,065 & 114,065 & 3.18 \\
Penyemprotan & HKO & 5 & 19,750 & 101,935 & 101,935 & 2.84 \\
Panen & HKO & 23 & 15,500 & 360,000 & 360,000 & 10.03 \\
Penjemuran & HKO & 18 & 16,000 & 280,774 & 280,774 & 7.83 \\
Pengangkutan & HKO & 9 & 17,750 & 164,903 & 164,903 & 4.60 \\
\hline TOTAL BIAYA VARIABEL & & & $\mathbf{3 , 5 8 7 , 7 9 2}$ & $\mathbf{1 0 0 . 0 0}$ \\
\hline
\end{tabular}

Biaya tetap meliputi pajak lahan dan penyusutan peralatan. Karena semua petani melakukan usahataninya di lahan milik sendiri maka biaya yang dikeluarkan adalah biaya pajak lahan. Dan bila petani melakukan usahataninya pada lahan milik orang lain dengan jalan menyewa maka biaya yang dikeluarkan oleh petani adalah biaya sewa. Sedangkan untuk biaya variabel meliputi pembelian pupuk, pestisida, biaya irigasi, biaya transport dan upah tenaga kerja. Tenaga kerja yang digunakan adalah tenaga kerja untuk sanitasi dan pemupukan pertama, sanitasi dan pemupukan kedua, serta pemanenan.

\section{Pajak Lahan}

Karena seluruh lahan yang dipakai untuk usahatani kedelai di Desa Klompang Barat adalah lahan milik sendiri, maka biaya yang dipakai adalah pajak lahan. Pajak lahan ialah biaya yang harus dikeluarkan oleh petani untuk membayar pajak atas lahan yang dimilikinya dalam melakukan usahatani kedelai. Sedangkan bila petani melakukan usahataninya pada lahan milik orang lain dengan jalan menyewa, maka biaya yang dipakai adalah biaya sewa. Biaya pajak lahan yang dikeluarkan petani sebesar $\mathrm{Rp} 60,774,-$ per hektar.

\section{Pupuk}

Pupuk yang digunakan pada usahatani kedelai di daerah penelitian adalah pupuk Urea dan TSP. Dosis yang diberikan kepada tanaman berbeda-beda menurut kebutuhan tanaman, kebiasaan petani, pengalaman dan ketersediaan modal. Biaya pembelian Benih rata-rata per hektar sebesar $\quad R p$ 310,339,dengan harga/Kg sebesar Rp 6,775 dan pemakaian rata-rata sebanyak $46 \mathrm{~kg}$. Pupuk Urea rata-rata per hektar sebesar Rp 423,188,- dengan harga/Kg Rp 2,085 dan pemakaian rata-rata sebanyak 203 kg. Sedangkan Biaya pembelian pupuk TSP rata-rata per hektar sebesar Rp 209,119 dengan harga/Kg Rp 2,205 dan pemakaian rata-rata sebanyak $95 \mathrm{~kg}$. 


\section{Pestisida}

Hama yang menyerang tanaman kedelai di daerah penelitian sebagian besar adalah Ulat, Belalang dan Kutu loncat / Kutu-kutuan . Maka jenis pestisida yang digunakan adalah Kanon, Drusban dan Buldog untuk menanggulangi Ulat, Belalang, dan Kutu loncat / Kutu-kutuan. Sedangkan Pupuk cair untuk tambahan unsure hara yang diberikan lewat daun atau tanah.

\section{Tenaga Kerja}

Tenaga kerja yang diperlukan dalam usahatani kedelai di daerah penelitian adalah tenaga kerja olah tanah,penanaman,penyiangan, pemupukan I,II dan penyemprotan . Tenaga kerja yang ada di daerah penelitian adalah tenaga kerja borongan. Biaya Tenaga kerja sebesar Rp $1,457,581$.

Dari uraian masing-masing biaya yang telah dijelaskan di atas dapat dihitung besarnya biaya variabel usahatani kedelai. Biaya variabel yang dikeluarkan petani kedelai di Desa Klompang Barat ini meliputi biaya Benih, Pupuk, Pestisida, Tenaga Kerja, dan Transportasi.

Tabel 2. Biaya Total Usahatani Kedelai per Ha di Desa Klompang Barat

\begin{tabular}{|c|c|c|}
\hline $\mathrm{No}$ & Uraian & Nilai ( $\mathrm{Rp}$ ) \\
\hline 1. & Biaya Tetap & $60,774,-$ \\
\hline 2. & Biaya Variabel & $3,587,792,-$ \\
\hline & Total Biaya & $3,648,566,-$ \\
\hline
\end{tabular}

Berdasarkan Tabel 2, dapat dilihat bahwa Biaya total merupakan penjumlahan antara biaya tetap dengan biaya variabel. Biaya tetap yang dikeluarkan di daerah penelitian yaitu sebesar Rp 60,774,-. Biaya variabel yang dikeluarkan di daerah penelitian yaitu sebesar Rp 3,587,792,-. Sehingga biaya total yang dikeluarkan petani dalam berusahatani Kedelai di daerah penelitian yaitu di Desa Klompang Barat sebesar Rp 3,648,566,--

\section{Penerimaan Usahatani Kedelai}

Penerimaan usahatani Kedelai didapatkan dari perkalian antara jumlah produksi dengan harga yang berlaku di daerah penelitian. Dari seluruh responden yang diambil, petani menjual produksi Kedelai secara langsung kepada pengumpul dan dijual sendiri ke pasar. 
Tabel 3. Penerimaan Usahatani Kedelai per Ha per Musim tanam di Desa Klompang Barat.

\begin{tabular}{llr}
\hline No & Uraian & Nilai ( Rp ) \\
\hline 1. & Produksi $(\mathrm{Kg})$ & 921 \\
2. & Harga (Rp) & 5,545 \\
3. & Penerimaan ( Rp ) & $5,108,642$ \\
\hline
\end{tabular}

Berdasarkan Tabel 3, dapat menggunakan Analisis R/C Ratio dilihat bahwa secara keseluruhan rata (Revenue Cost Ratio) atau yang dikenal - rata Penerimaan dari usahatani dengan perbandingan ( nisbah ) antara Kedelai per $\mathrm{Ha}$ per Musim Tanam penerimaan dengan total biaya Produksi. sebesar $921 \mathrm{~kg}$ dengan harga Rp 5,545,- Untuk lebih jelasnya pada tabel dibawah /kg. Maka didapatkan penerimaan ini disajikan R/C Ratio usahatani kedelai sebesar Rp 5,108,642,-

\section{Analisa R/C Ratio}

di Desa Klompang Barat Kecamatan Pakong Kabupaten Pamekasan.

Usahatani kedelai secara
ekonomi menguntungkan di daerah
penelitian dapat diketahui dengan

Tabel 4. R/C Ratio Per Musim Tanam di Desa Klompang Barat

\begin{tabular}{c|l|r}
\hline No & \multicolumn{1}{|c|}{ Uraian } & Nilai Uang ( Rp ) \\
\hline 1. & Penerimaan ( Rp/ Ha Musim Tanam ) & $5,108,642,-$ \\
2. & Biaya produksi ( Rp / Ha Musim Tanam ) & $3,265,452,-$ \\
3. & R/C & 1,56 \\
\hline
\end{tabular}

Berdasarkan Tabel 4, dapat usahatani kedelai secara ekonomis dilihat bahwa secara keseluruhan rata menguntungkan di daerah penelitian rata R/C Ratio dari usahatani kedelai per dapat diterima, karena rata - rata $\mathrm{R} / \mathrm{C}$ musim tanam adalah sebesar 1,56 Ratio adalah sebesar 1,56 yang dengan penerimaan sebesar $\mathrm{Rp}$ menunjukkan bahwa dengan biaya / $5,108,642,-$ dan biaya produksi sebesar modal usaha sebesar Rp 5,108,642,- dan Rp 3,265,452,- . Hal ini menunjukkan Rp 3,265,452,- maka akan diperoleh bahwa hipotesis yang menyatakan penerimaan 1,56 kali lipat, dengan kata 
lain hasil penjualan kedelai mencapai $156 \%$ dari modal yang dikeluarkan. Bila $\mathrm{R} / \mathrm{C}>1$ maka petani kedelai tersebut untung.

\section{Analisa Pendapatan Usahatani \\ Kedelai \\ Analisa Pendapatan adalah selisih antara penghasilan total (TR)}

dengan pembiayaan total (TC). Secara keseluruhan rata - rata pendapatan bersih usahatani kedelai dalam satu musim tanam. Untuk lebih jelasnya pada tabel dibawah ini disajikan pendapatan bersih usahatani kedelai di Desa Klompang Barat Kecamatan Pakong Kabupaten Pamekasan.

Tabel 5. Pendapatan Bersih Usahatani Kedelai Per Ha Per Musim Tanam di Desa Klompang Barat.

\begin{tabular}{ccr}
\hline No & Uraian & Nilai ( Rp ) \\
\hline 1. & Penerimaan ( Rp/Ha Musim Tanam ) & $5,108,642,-$ \\
2. & Biaya produksi ( Rp/Ha Musim Tanam ) & $3,265,452,-$ \\
\hline & Jumlah & $1,843,191,-$ \\
\hline
\end{tabular}

Berdasarkan Tabel 5, dapat diketahui bahwa secara keseluruhan rata - rata pendapatan bersih usahatani kedelai per musim tanam adalah sebesar Rp 1,843,191,- dengan penerimaan sebesar Rp 5,108,642,- di kurangi biaya produksi sebesar Rp 3,265,452,-- Hal ini menunjukkan bahwa petani di Desa Klompang Barat Kecamatan pakong Kabupaten Pamekasan pendapatan petani sudah mencukupi. Hal ini menunjukkan bahwa hipotesis yang menyatakan bahwa pendapatan bersih usahatani kedelai di daerah penelitian lebih besar, maka pendapatan bersih dapat diterima.

Namun kehidupan masyarakat petani di Desa Klompang Barat masih belum sejahtera karena pendapatan petani kedelai di daerah penelitian tidak selalu stabil, terkadang mereka tidak memperoleh pendapatan sama sekali dari usahatani kedelai yang mereka usahakan dan bahkan mengalami kerugian. Dalam hal ini para petani tidak memperoleh pendapatan sama sekali, jika petani mengalami kerugian yaitu dari masalah pemasaran dengan harga jual yang rendah dan produksi yang tidak laku dijual.

\section{KESIMPULAN DAN SARAN}

\section{Kesimpulan}

Berdasarkan hasil penelitian dan pembahasan tentang Usahatani Kedelai 
(Glycine max (L.) Merrill) di Desa Klompang Barat Kecamatan Pakong Kabupaten Pamekasan dapat disimpulkan sebagai berikut :

a) Biaya produksi usahatani Kedelai secara ekonomis di daerah penelitian adalah menguntungkan yaitu rata rata $\mathrm{R} / \mathrm{C}$ Ratio Per Musim Tanam adalah 1,56. Dari hasil Penerimaan ( TR ) yaitu sebesar Rp 5,108,642,dibagi Total Produksi ( TC ) yaitu sebesar Rp 3,265,452,. Dan Pendapatan bersih usahatani kedelai di daerah penelitian sudah mencukupi yaitu sebesar $\mathrm{Rp}$ 1,843,191,-. Dari hasil Penerimaan ( TR ) yaitu sebesar Rp 5,108,642,dikurangi Total Produksi ( TC ) sebesar Rp 3,265,452,- .

b) Produksi, Luas lahan, Pupuk, Tenaga kerja, Pendidikan dan Pengalaman bertani sangat berpengaruh terhadap usahatani kedelai di daerah penelitian.

\section{Saran}

a) Petani sebaiknya menggunakan bibit tanaman kedelai yang berkwalitas unggul yaitu varietas willis yang cocok untuk lahan litosol di Desa Klompang Barat.

b) Perlu adanya peningkatan fungsi kelompok tani dan pelatihan tanaman kedelai yang unggul, yang ada sekarang benar - benar dapat membantu petani dalam penyediaan sarana produksi pertanian.

c) Untuk peneliti selanjutnya di Fakultas pertanian yang berkeinginan untuk meneliti/melakukan penelitian lebih lanjut tentang tanaman kedelai sebaiknya meneliti tentang tataniaga dan pemasaran kedelai di Desa Klompang Barat.

\section{DAFTAR PUSTAKA}

ВРТР ,1999. Acuan Rekomendasi Pemupukan Spesifik Lokasi Tanaman Kedelai di Jawa Timur. Balai Pengkajian Teknologi Pertanian Karangploso.

http://BPSK KalimantanTengah.setjen.dept an.go.id/berita/detail.php?id=20 2,2009. 23/03/2012

http://Deptan.go.id/xplore/files/PASCA PANEN/Potensi/kedelai/2009.2 $\underline{2 / 03 / 2012}$

http://id.wikipedia.org/wiki/Kedelai. 22/03/2012.

http://Setneg.go.id/Kedelai-nasional/, 2009. 23/03/2012.

http://plantamor.com/ KlasifikasiKedelai/index.php?,2009.plant 24/03/2012.

http://makalahbiologiku.blogspot.com/2 010/07/tanaman-kedelai.html 26/03/12.

Koentjaraningrat, 1991. Metode-Metode Penelitian Masyarakat. PT. 
Gramedia Pustaka Utama: Jakarta.

Rangkuti, Freddy. 2008. Analisis SWOT : Teknik Membedah Kasus Bisnis-Reorientasi Konsep Perencanaan Strategis untuk Menghadapi Abad 21/ Jakarta : Gramedia Pustaka Utama.

Syamsudin, Lukman. 2007. Manajemen Keuangan Perusahaan : Konsep
Aplikasi dalam : Perencanaan, pengawasan, dan Pengambilan Keputusan. Ed. - Baru - 9. PT

Raja Grafindo Persada : Jakarta.

Simamora, Bilson. 2004. Riset Pemasaran : Falsafah, Teori, dan Aplikasi. PT Gramedia Pustaka Utama : Jakarta.

Soekartawi, 1995. Analisis Usahatani. UI. Press : Jakarta 